\title{
STERILIZABLE MINIATURE BIOREACTOR PLATFORM FOR ANAEROBIC FERMENTATION PROCESS
}

\author{
Muhammad Zainuddin Arriafdi' ${ }^{1 a}$, Arvind Ramachendrin ${ }^{2 b}$, Muhd Nazrul Hisham \\ Zainal Alam ${ }^{3 a^{*}}$
}

\begin{abstract}
aDepartment of Bioprocess and Polymer Engineering, School of Chemical and Energy Engineering, Faculty of Engineering, Universiti Teknologi Malaysia, 81310 UTM Johor Bahru, Johor, MALAYSIA. Email: zainuddinarriafdi@gmail.com ${ }^{1}$; nazrulhisham@utm.my ${ }^{3}$

${ }^{b}$ Production Drug Substance, Biocon Sdn Bhd, Kawasan Perindustrian SILC, 79200 Iskandar Puteri, Johor, MALAYSIA. Email: vahgardnivra@gmail.com²

Corresponding author: nazrulhisham@utm.my

Received: $5^{\text {th }}$ Sep $2019 \quad$ Accepted: $6^{\text {th }}$ Oct 2020

Published: $28^{\text {th }}$ Feb 2021
\end{abstract}

DOI: https://doi.org/10.22452/mjs.vol40no1.2

\begin{abstract}
This paper presents the establishment of a miniature bioreactor platform for anaerobic microbial fermentation processes. It is made from a universal glass bottle and has a working volume of $16 \mathrm{~mL}$. Reactor features included mixing via magnetic stirrer, temperature control via electrical heater and cells optical density (OD) sensing. All sensors and actuators integrated into the reactor were operated using LabVIEW ${ }^{\mathrm{TM}}$ (National Instrument, TX, US). The top lid of the bottle was modified to include a $3 \mathrm{~mm}$ poly(methylmethacrylate) (PMMA) polymer layer where it was machined to provide spaces for fluidic ports and integration of sensors. Each reactor components were sterilized prior to conducting fermentation experiments. Main body of the reactor was made of glass and it was sterilized using the standard heat sterilization method $\left(121^{\circ} \mathrm{C}\right.$ for 15 minutes $)$ where else other components were sterilized by exposure to UV light for 2 hours. A series of anaerobic fermentation experiments were conducted in batch mode using S.cerevisiae to evaluate the workability of the system. Fermentation experiments were conducted using inoculum concentration of $2 \mathrm{~g} \cdot \mathrm{L}^{-1}$ and starting glucose concentration between $10 \mathrm{~g} \cdot \mathrm{L}^{-1}$ and $20 \mathrm{~g} \cdot \mathrm{L}^{-1}$. In every experiment, mixing was set to operate at $400 \mathrm{rpm}$ and temperature was adjusted to $30 \pm 2^{\circ} \mathrm{C}$. Experiments were carried out until stationary phase was attained. Under these conditions, the best fermentation profile was obtained with glucose concentration of $20 / \mathrm{L}$ where cell specific growth rate was found to be about $0.28 \mathrm{~h}^{-1}$. Bench marking step was also performed where results attained in a miniature bioreactor platform were comparable with the one attained using a $50 \mathrm{~mL}$ flask.
\end{abstract}

\begin{abstract}
ABSTRAK Kertas ini mempersembahkan sebuah prototaip bioreaktor berskala miniatur bagi proses fermentasi mikrorganisma anarobik. Ia dihasilkan daripada sebuah botol kaca universal dan mempunyai isipadu operasi sebanyak $16 \mathrm{~mL}$. Reka bentuk bioreaktor ini mengandungi sebuah alat pemanas, penderia suhu, pembaca ketumpatan (OD) sel dan pengadukan melalui 'stirrer bar' magnetik. Kesemua sensor dan prob yang diintegrasi dalam bioreaktor boleh dikawal dengan perisian LabVIEW ${ }^{\mathrm{TM}}$ (National Instrument, TX, US). Penutup botol universal telah dimodifikasi untuk meletakkan lapisan polimer poly(methylmethacrylate) (PMMA) tambahan di mana ia digunakan bagi perletakkan laluan bendalir dan kemasukan penderia-penderia. Setiap komponen bioreaktor disteril sebelum eksperimen fermentasi anarobik dilakukan. Badan bioreaktor disterilisasi dengan kaedah sterilisasi haba $\left(121^{\circ} \mathrm{C}\right.$ untuk 15 minit) manakala komponen yang lain disterilisasi dengan pendedahan kepada cahaya UV selama 2 jam. Eksperimen fermentasi anarobik dijalankan dalam mod sistem tertutup dengan mengunakan sel $S$. cerevisiae sebagai piawai untuk uji
\end{abstract}


keberkesanan bioreaktor miniatur bagi fermentasi anarobik. Eksperimen dijalankan pada saiz inokulum $2 \mathrm{~g} \cdot \mathrm{L}^{-1}$ dengan kepekatan media glukosa antara $10 \mathrm{~g} \cdot \mathrm{L}^{-1}$ hingga $20 \mathrm{~g} \cdot \mathrm{L}^{-1}$. Dalam setiap eksperimen pengadukan dikawal pada kelajuan 400rpm dan suhu bioreaktor diselaraskan pada $30 \pm 2^{\circ} \mathrm{C}$. Reaksi dijalankan sehingga fermentasi mencapai fasa pengun. Profil fermentasi yang terbaik diperolehi pada kepekatan glukosa $20 \mathrm{~g} \cdot \mathrm{L}^{-1}$ dimana kadar pertumbuhan sel adalah 0.28 $\mathrm{hr}^{-1}$. Ekperimen perbandingan juga dijalankan dan keputusan yang diperolehi bioreaktor miniatur adalah yang sama dengan ekperimen mengunakan $50 \mathrm{~mL}$ kelalang.

Keywords: Miniature bioreactor, anaerobic fermentation, scale down, miniaturization, S.cerevisiae

\section{INTRODUCTION}

Bioreactors are main unit operations in many biochemical processes in which enzymes, microbial, mammalian, or plant cell systems are used for manufacture of a wide range of useful products (Najafpour, 2007; Blose et al., 2014). At laboratory settings, fermentation experiments are often conducted by using shake flasks and the bench-top bioreactors. Shake flasks in general are useful but are usually not integrated with sensors and actuators. Therefore, experiments performed generate limited amount of process information. Bench scale bioreactor on the other hand consist of various sensors and actuators however experimentation are rather costly as larger amounts of raw materials are needed per experiment. Moreover, it is laborious to work with because heavy lifting is required for sterilization of medium within the reactor, and post-operation would require thorough cleaning and another round of sterilization. Moreover, sampling is needed for both experimental setup and this may risk broth contamination and troublesome for extended fermentation experiments.

Miniature bioreactors (MiBR) are potential scaled down bioreactor device for conducting biological experiments. It is regarded as a bioreactor system with working volume usually less than $20 \mathrm{~mL}$ (Kirk and Szita, 2013; Bolic, 2018). They can be fabricated to have the similar features as the typical bench scale bioreactor setup. These include integrated sensors for measurement of fermentation physical data and inclusion of miniature pumps to transport liquid to or from the reactor for nutrient supply or for harvesting purposes. Development of MiBRs have received increasing attention from acedemia and industry. To date, MiBRs have been applied in various research areas particularly on process development of biotechnology fermentation processes (Kheradmandnia et al, 2014). Clearly, MiBRs have the advantage in reducing the fermentation development time offer a less laborious operations, inexpensive to work with and enables in situ evaluation of process change for an existing operation (Schmideder et al., 2015).

In this work, we report the establishment of a sterilizable miniature bioreactor platform. The reactor has a working volume of $16 \mathrm{~mL}$. The idea was to design a sterilizable bioreactor system at the milliliter scale that can be fabricated inexpensively. The reactor also should be easy to operate i.e. plug ' $n$ ' play reactor platform. The concept of simple-to-use is referred to the handling of the reactor where it should be easy to use with fast installation similar to a typical shake flask operation. In the process of making the reactor economical, the essential components of the miniature bioreactor were built on a discrete platform so that it can be re-used. The reactor was designed to include 
necessary features for carrying out fermentation experiments. These include mixing, temperature control, and online optical sensing for cells density. The latter would allow one to utilize the reactor for lengthly fermentation experiment without the need for sampling.

In order to test the workability of the proposed MiBR system, anaerobic yeast fermentation experiments were carried out. Anaerobic fermentation is a metabolic process that occurs under the conditions where oxygen is not present and it has a long history of industrial applications for the production of food and chemicals. In addition, anaerobic fermentation in recent years has seen a steep rise especially in the bioremediation, brewery and biofuel industries (Panatto et al., 2015). The effect of substrate (glucose) concentration was caried and cells OD was monitored until cells came to stationary phase. In making the MiBR suitable for microbial fermentation, several tests were performed to study the workability of the MiBR system for anaerobic fermentation i.e. mixing efficiency and quality was tested via the decolorization-tracer method using bromothymol blue (BTB) tracer solution. Meanwhile, effectiveness of temperature control in the MiBR were tested with control efficiency and response time test, to ensure optimum temperature is maintained during the fermentation reactions. Optical fibers were used for cell density measurement which allowed for the observation of cell growth in real time without the need for sampling. Moreover, sterility testing (media hold study) was performed to determine the effectiveness of the sterilization technique used to control contamination. Anaerobic fermentation experiments were performed with S.cerevisiae cells at various glucose concentration and the cell doubling time and growth rate were calculated at the end of each reaction.

\section{MATERIALS AND METHODS}

\subsection{Design and Fabrication of the Miniature Bioreactor}

A small universal sampling glass bottle was modified to create the miniature bioreactor prototype. It has a diameter and height of about $28 \mathrm{~mm}$ and $67 \mathrm{~mm}$, respectively. This gives a total volume of about $28 \mathrm{~mL}$. In each experiment, only 16 $\mathrm{mL}$ of volume was utilized to provide room for headspace. Headspace is necessary for gas exchange or for removal of bubbles. The top lid of the bottle was modified to include a $3 \mathrm{~mm}$ poly(methylmethacrylate) (PMMA) polymer layer with similar diameter. Holes were created on the polymer layer for establishment of fluidic ports and for insertion of electrical heater and the Pt100 temperature sensor. Fluidic ports were realized using a stainless steel tube (outer diameter $\sim 3 \mathrm{~mm}$ and inner diameter $\sim 2 \mathrm{~mm}$ ). Two ports were created and the ports are reserved for delivery of liquid into/from the reactor and releasing of gas. Gas outlet port is connected to a small $0.2 \mu \mathrm{m}$ NALGENE $^{\mathrm{TM}}$ nylon syringe filter to prevent any contamination from the surroundings. A $24 \mathrm{~V} 150 \mathrm{~W}$ stainless steel electrical heater with diameter of $6 \mathrm{~mm}$ was integrated through the middle part of the lid. Epoxy was used to glue all fluidics ports and the electrical heater in place. In addition, a poly(dimethylsiloxane) (PDMS) gasket was customized for sealing of the cap. This would also ensures a water tight connection and prevent any leakages. The PDMS liquid solution was prepared by mixing 10 parts silicone and 1 part curing agent (Sylgard 184, Dow Corning). After degassing, the pre-polymer solution was poured into the bottle cap and left to solidify in room temperature. A small magnetic stirrer $(10 \mathrm{~mm}$ [length] $\times 2 \mathrm{~mm}$ [width]) was placed on the reactor floor to provide necessary mixing for the miniature bioreactor operation. During operation, the 
reactor is placed on an operating platform consisting of a mechanical PC fan. The PC fan was operated using a $5 \mathrm{~V}$ DC power supply and small magnets were glued on the PC fan to create the necessary magnetic coupling with the magnetic stirrer bar. Stirring is achieved based on the rotating speed of the PC fan. Pt-100 temperature sensor (CLS 181-2012 Correge, France) is used to measure the temperature of the reactor content during operation. The sensor is attached on the outer wall and at the bottom of the reactor for easier temperature measurement. Monitoring of cells optical density was based on cells optical sensing methodology applied in microbioreactors prototype (Alam,
Schäpper \& Gernaey, 2010, Halimoon, Hussain, Kouzani \& Alam, 2016). The optical components were placed on a probe holder on each end of the miniature bioreactor. A low-cost plastic transmitter (SFH756, Avago Technologies, us) was used to transmit a bright yellow LED light (modulated square wave) from the reference probe at $47 \mathrm{~Hz}(5 \mathrm{v}$ current signal $)$ through the chamber of the miniature bioreactor and is then collected by the receiver photodetector probe (PD) (SFH250, Avago Technologies, US) with similar configuration as the transmitter probe (Zainal Alam et al., 2018). Schematic of the miniature bioreactor platform is illustrated in Figure 1.
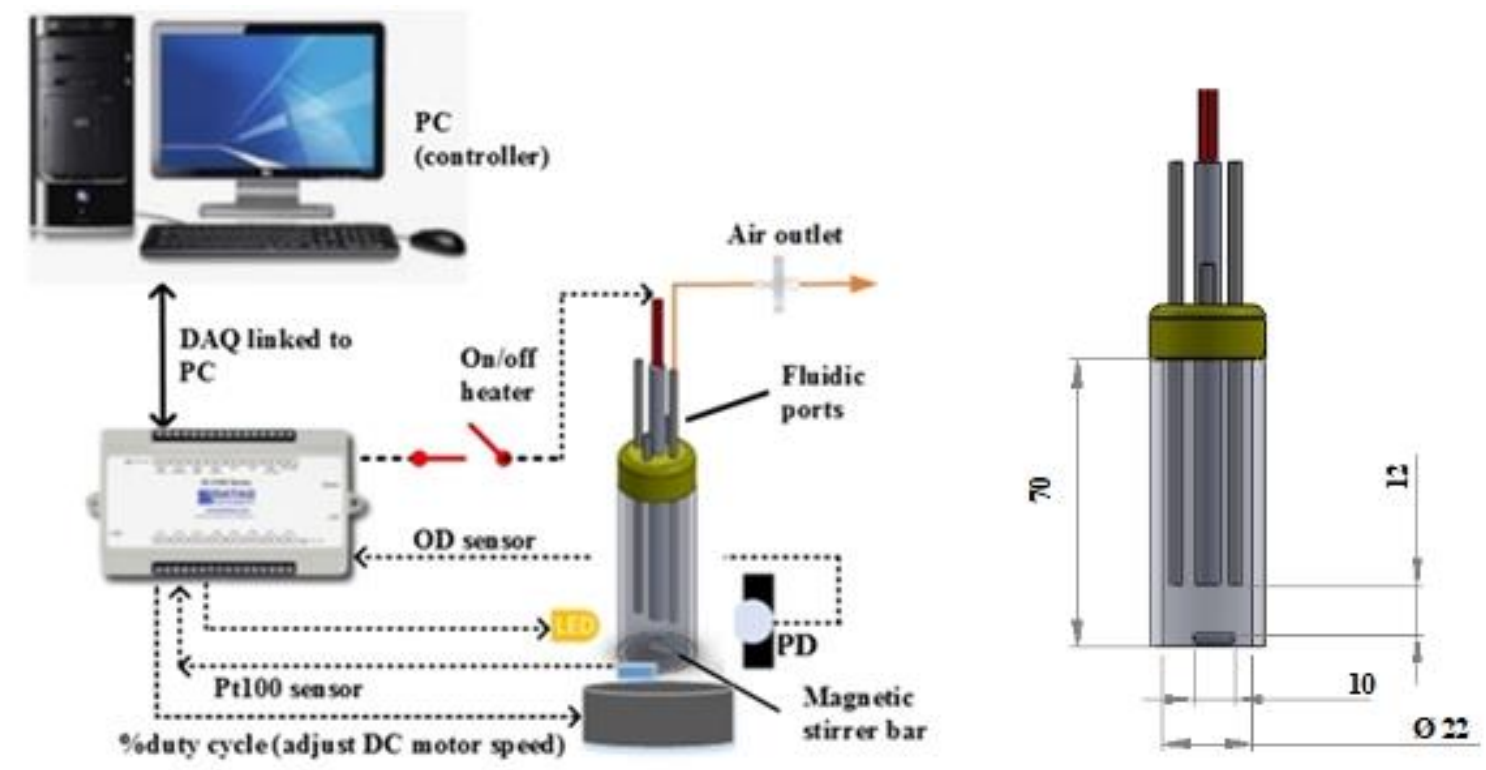

Figure 1. Schematic diagram of the miniature bioreactor platform (left) and the details of the reactor geometry (right). The miniature bioreactor was placed on an operating platform which consist of a 5V DC mechanical fan for stirring. Other sensors (Pt100 and OD sensors) and the electrical heater are linked directly to the NI USB 6343 DAQ for input and output of signals.

\subsection{Process Control and Automation of the Miniature Bioreactor}

Temperature was the only parameter controlled where else cells optical density were measured using optical fibers and stirring is set through open loop step. Temperature control was achieved via on-/off controller technique developed by
Zainal Alam et al. (2010). First, temperature readings $\left(\mathrm{T}_{\mathrm{m}}\right)$ were attained from the Pt100 temperature sensor. Analog voltage signals from the sensor was first linearized and converted to temperature values $\left({ }^{\circ} \mathrm{C}\right.$ ) via a transmitter (JUMO dTRA NS T04, JUMO GmbH \& Co., Fulda, Germany) before connected to $t$ he NI USB 6343 DAQ for futher 
processing. Then, the controller (written in LABVIEW) will compute the differences between the measured values $\left(\mathrm{T}_{\mathrm{m}}\right)$ and the desired set point values, $T_{\mathrm{sp}}$. If $\mathrm{T}_{\mathrm{sp}}$ is more than $T_{m}$, the heater is turned on until $T_{s p}$ is achieved; otherwise it will remained in an off state. Heating was achieved by passing electric current at 7V DC to the stainless steel electrical heater. Heats created by the electrical heater was distributed constantly by the rotating magnetic stirrer. The effectiveness of the temperature control algorithm applied was assessed based on control accuracy and Pt100 sensor response time. Evaluation were done by assessing the parameters at different heater on-/off pulse duties and voltage supply. The speed of the magnetic stirrer bar was determined using a hall effect sensor when connected to $5 \mathrm{~V}$ DC power supply. Throughout the reactor operation, rotating speed of the magnetic stirrer bar was not controlled and operated at the same power supply.

Cells optical density was calculated using Beers Lambert law based on tranmittance data collected from the PD. A calibration curve was generated using yeast cells suspended in distilled water at concentration range between $5 \mathrm{~g} \cdot \mathrm{L}^{-1}$ and 25 $\mathrm{g} \cdot \mathrm{L}^{-1}$. Each sample was loaded into the miniature bioreactor for OD measurement. OD values was attained based on the correlation between the ratio of transmitted and collected analog voltage signals attained $\left(\mathrm{Vs}_{\mathrm{s}} / \mathrm{V}_{\mathrm{T}}\right)$ and different yeast sample concentration (Zainal Alam et al., 2018). A program for automation of the reactor was written in LabVIEW ${ }^{\mathrm{TM}}$ Academic Premium Suite software. The program was executed by interfacing the reactor with NI USB 6343 DAQ for in- and output of signals.

\subsection{Mixing Quality and Method to Determine pH Change in the Miniature Bioreactor}

Mixing quality of the reactor was assessed through colourization-tracer method with the use of $0.5 \% \quad\left({ }^{\mathrm{w}} / \mathrm{v}\right)$ bromothymol blue (BTB) tracer. BTB was prepared by dissolving $0.5 \mathrm{~g}$ of $\mathrm{BTB}$ powder (QreC) into $15 \mathrm{~mL}$ of $0.02 \mathrm{~N}$ sodium hydroxide, $\mathrm{NaOH}$ solution (QreC). The final $\mathrm{pH}$ of the solution was adjusted to $7.0 \pm 0.2$ with $1 \mathrm{M} \mathrm{NaOH}$ solution. Experiment was conducted by using a distilled water. The time taken for tracer to completely mix with the contents of the miniature bioreactor were recorded and observed using APPLE ${ }^{\circledR}$ Iphone 7 camera.

There is no $\mathrm{pH}$ probe installed in the current miniatue bioreactor setup due to limited spaces. On this reason, a qualitative tool of using colourimetric $\mathrm{pH}$ indicator was applied to predict the $\mathrm{pH}$ of the reactor content. $0.5 \% \quad(\mathrm{w} / \mathrm{v})$ BTB indicator was again utilized where it was added into the media. The solution was prepared by mixing $0.5 \mathrm{~g}$ of $\mathrm{QReC}{ }^{\circledR} \mathrm{BTB}$ powder into $10 \mathrm{~mL}$ of $0.02 \mathrm{~N} \mathrm{NaOH}$ solution and $90 \mathrm{~mL}$ of distilled water. Changes of $\mathrm{pH}$ can be detected by observing the color change of the reactor content for increasing and decreasing of $\mathrm{pH}$. If the $\mathrm{pH}$ of the solution is within the acidic region $(\mathrm{pH}<7)$, a yellow colored solution is to be expected. On contrary, if the $\mathrm{pH}$ of the solution is greater than $\mathrm{pH} 7$, the color of the solution will be in blue indicating the solution is within the alkaline region.

\subsection{Anaerobic Fermentation in Miniature Bioreactor}

S. cerevisiae batch anaerobic fermentation experiments were performed to demonstrate the workability of the miniature bioreactor platform. The inoculum concentration of yeast cells used in anaerobic fermentation experiments were kept constant at $2 \mathrm{~g} \cdot \mathrm{L}^{-1}$ by weighing equal amounts of wet yeast cells (Mauripan, UK) and mixed with $500 \mu \mathrm{L}$ of fresh and sterilized glucose medium. The final volume of inoculum was prepared at 1.6 $\mathrm{mL}$ and was used for the experiments $(10 \%$ $(\mathrm{v} / \mathrm{v})$ of the total working volume). A Yeast 
Extract-Peptone-Dextrose (YPD) medium was used to carry out all experiments. Glucose concentration in fermentation media was varied in each experiment i.e. between $10 \mathrm{~g} \cdot \mathrm{L}^{-1}$ and $20 \mathrm{~g} \cdot \mathrm{L}^{-1}$. During media preparation, $\mathrm{pH}$ of solution was adjusted to $7.0 \pm 0.2$ using $1 \mathrm{M}$ sodium hydroxide, $\mathrm{NaOH}$ solution and $1 \mathrm{M}$ of hydrochloric acid, HCL. The media was heat sterilized at $121^{\circ} \mathrm{C}$ for 15 minutes. Once cooled, $15 \mathrm{~mL}$ of freshly prepared glucose media was aseptically transferred into the miniature bioreactor which then followed with the addition of $1.6 \mathrm{~mL}$ inoculum culture.

Before addition of the medium, the miniature bioreactor was first sterilized. The main body of the reactor was subjected to heat sterilization for 15 minutes at $121^{\circ} \mathrm{C}$ meanwhile the cap together with its fluidic ports were first sprayed with $70 \%(\mathrm{v} / \mathrm{v})$ ethanol solution followed by rinsing with distilled water. The cap was then exposed to ultraviolet (UV) light in a NUAIRE ${ }^{\circledR}$ class (II) biosafety cabinet for 2 hours. They were then re-assembled under laminar air flow prior to begin the fermentation experiment. Medium and inoculum transfer were all done in a NUAIRE $^{\circledR}$ class (II) biosafety cabinet under laminar air flow. Finally, two $\mathrm{mL}$ of vegetable oil was added to create a thin hydrophobic layer on the surface of the liquid layer. This is essential to prevent the entry of oxygen molecules into the media and also to ensure an anaerobic reaction condition. All fermentation reaction was carried out at $30^{\circ} \mathrm{C}$ and at stirring rate of about $400 \mathrm{rpm}$. The progress of the fermentation was monitored until cells growth reach the stationary growth phase. Cells were monitored online whilst glucose level were estimated using DNS method from $0.4 \mathrm{~mL}$ sample taken from the reactor.

For comparison purposes, anaerobic yeast fermentation was also carried out using a shake flask. Similar media was used with working volume of 50
$\mathrm{mL}$. In the shake flask operation, $1 \mathrm{~mL}$ of samples were taken aseptically every hour to monitor the cells growth. For this purpose, cells OD was measured at $600 \mathrm{~nm}$ using a spectrometer where the cell-free media was used as blank.

\section{RESULTS AND DISCUSSION}

\subsection{Mixing capacity of the reactor}

One of the important design aspect in miniature bioreactor system is its mixing capacity. The mixing method employed for the reactor should uniformly mix the reactor content whilst ensuring very minimal dead zones (stagnant area). This is indeed a challenge because in small scale bioreactor system especially the ones with few milliliters working volume, turbulence mixing conditions often could not be met (Schäpper et al., 2009). Small reactor system also does not offer much room for installation of baffles and/or sophisticated impeller design. Moreover, miniature size impeller system is not so easy to design and it usually involved many fabrication steps (Bolic et al., 2016). In the miniature bioreactor system presented in the work, a miniature size magnetic stirrer bar was applied for mixing of the reactor content. The stirrer bar sits at the floor of the reactor and actuated using a rotating magnet placed underneath the reactor. The performance of the mixing strategy employed was evaluated using a dye decolorization technique. Dye decolorization method proved to be sufficient in observing the mixing flow pattern and to determine the magnetic stirrer bar mixing times at different rotational speed (Bolic et al., 201 6; Halimoon et al.,2016). Figure 2a depicts series of images taken at the point where the tracer was injected from the top liquid surface until a complete mixing condition was achieved within the period of two seconds. System was operated at mixing speed of $400 \mathrm{rpm}$ using a distilled water (no microbial activity) at room temperature and 
without any aeration.

As seen in Figure 2a, once the dye entered the liquid phase, it was pulled downwards into the central region of the reactor content before quickly spread towards to reactor wall following an axial mixing pattern that is usually evident in a Rushton turbine impeller system. In the presented miniature bioreactor system, the magnetic stirrer bar rotates steadily about a fixed vertical axis on the flat bottom surface of the reactor. The rotating stirrer bar created a stable circular flow pattern with a slight depleting funnel-like fluid structure on the liquid surface. A vortex flow pattern was not observed at any stirring speed applied. It is believed that the heater as well as the stainless tubes structure within the reactor somewhat also function similar to a baffle (Figure 2b). It prevents a huge swirling of the liquid at the central region of the reactor and therefore, avoid the formation of vortex. The mixing times decreased exponentially with the increase of stirrer bar rotational speed. It was also evident that optimal mixing times were attained at stirring speed of $400 \mathrm{rpm}$ which is about $2 \mathrm{~s}$ (Figure $2 \mathrm{~b}$ ). Increasing of the stirring speed above $400 \mathrm{rpm}$ do not improve the mixing times by much. Although the reactor content remained in laminar flow conditions $\left(\mathrm{N}_{\mathrm{Re}} \sim 7\right)$ at stirring speed of $400 \mathrm{rpm}$, no dead zones were detected and thus concluded that efficient stirring and mixing has been successfully achieved. The mixing capacity of the reactor was found to be comparable to other types of miniature bioreactor systems. At a size of liquid volume of few milliliters range and stirring speed ranging between $200 \mathrm{rpm}$ and $500 \mathrm{rpm}$, many reported that the mixing times are typically in the order of few seconds (less than 3s). (Bolic et al., 2016; Halimoon et al., 2016; Schmideder et al., 2015).

(a)

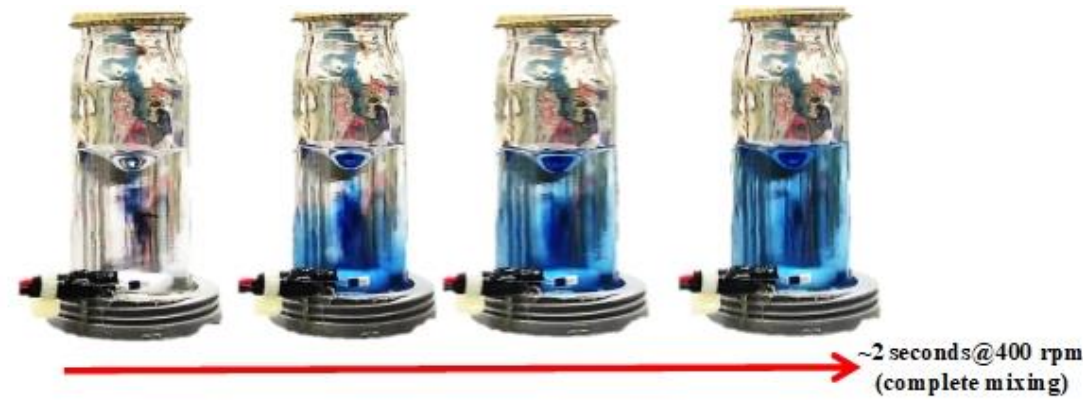

(b)
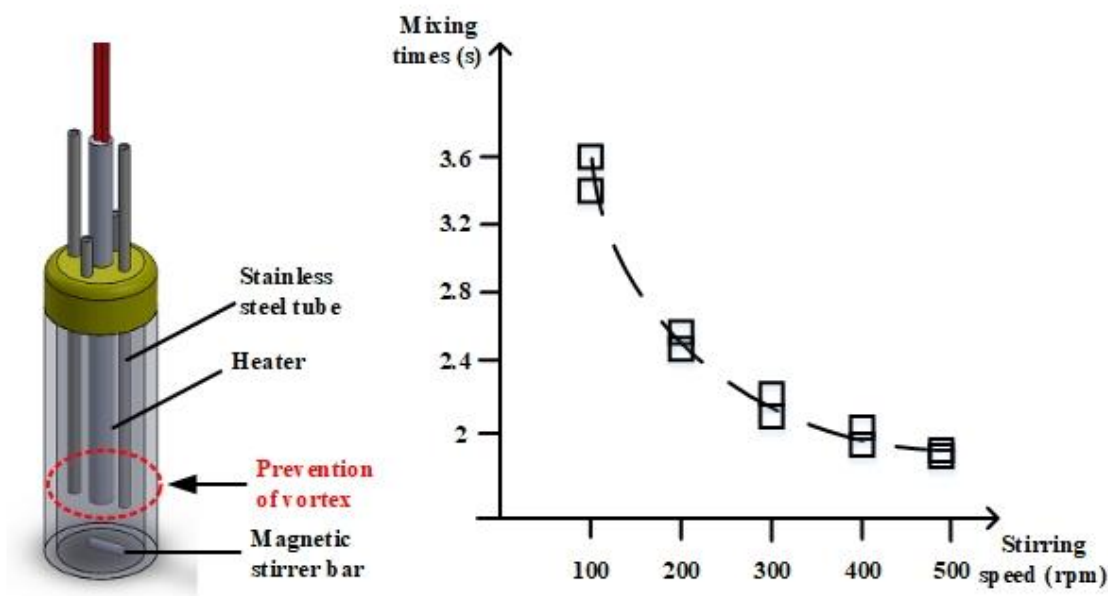

Figure 2. a) Series of images taken at the point where the tracer was injected from the top liquid surface until a complete mixing condition was achieved within the period of two seconds at $400 \mathrm{rpm}$. b) Positioning of the stainless tubes and the heater that functions as

baffles (left) and the mixing times of the reactor at different stirring speed (rpm). 


\subsection{Temperature control capability of the reactor}

The performance of the on/off temperature controller capacity employed in the proposed miniature bioreactor prototype was evaluated using the setpoint tracking experiments. The experiment was carried out by increasing the temperature of the reactor content at two different set-point values and the response and accuracy of the controller was assessed. Figure 3 shows the results of the temperature control set-point tracking experiments. Based on the results in Figure 3 , every time the temperature set-point values were adjusted, the heater immediately heat-up the system, and the temperature of the reactor content increases almost instantaneously. No delay was evident and the response time is less than a second. However, at higher temperature set-point values (i.e. when temperature was adjusted from $30^{\circ} \mathrm{C}$ to $37^{\circ} \mathrm{C}$ ), it was seen that the temperature response was a couple of seconds slower. It also took much longer time to reach the desired set-point value of $37^{\circ} \mathrm{C}$. This was expected as the driving force the heat transfer was the temperature difference $(\Delta \mathrm{T})$ between the temperature of the reactor and the ambient. If one would like to accelerate the heating step, higher heat load is required and this is not possible for on/off control algorithm. In on/off temperature control algorithm, the same amount of heat was being transferred into the reactor content every time during the heating step. Moreover, an overshoot by nearly $2^{\circ} \mathrm{C}$ above the set-point values was also evident. This could have been due to the fact that the heater is still warm due to continuous heating before switching off and heat transfer from the heater to the reactor content still occurring. Nevertheless, once the heater was turned off, the temperature of the reactor content slowly reduces reaching the desired temperature set-point values. No cooling element was installed in the presented miniature bioreactor setup and cooling was entirely depending on the heat loss to the surroundings. Overall, a satisfactory degree of control was achieved for the temperature parameter. The temperature controller accuracy was about $0.1-0.2^{\circ} \mathrm{C}$ from the temperature set point values. Surrounding temperatures do not have any significant effect on the stability of the temperature controller operation and the system are usable for temperature set-point values ranging between $25^{\circ} \mathrm{C}$ and $40^{\circ} \mathrm{C}$.

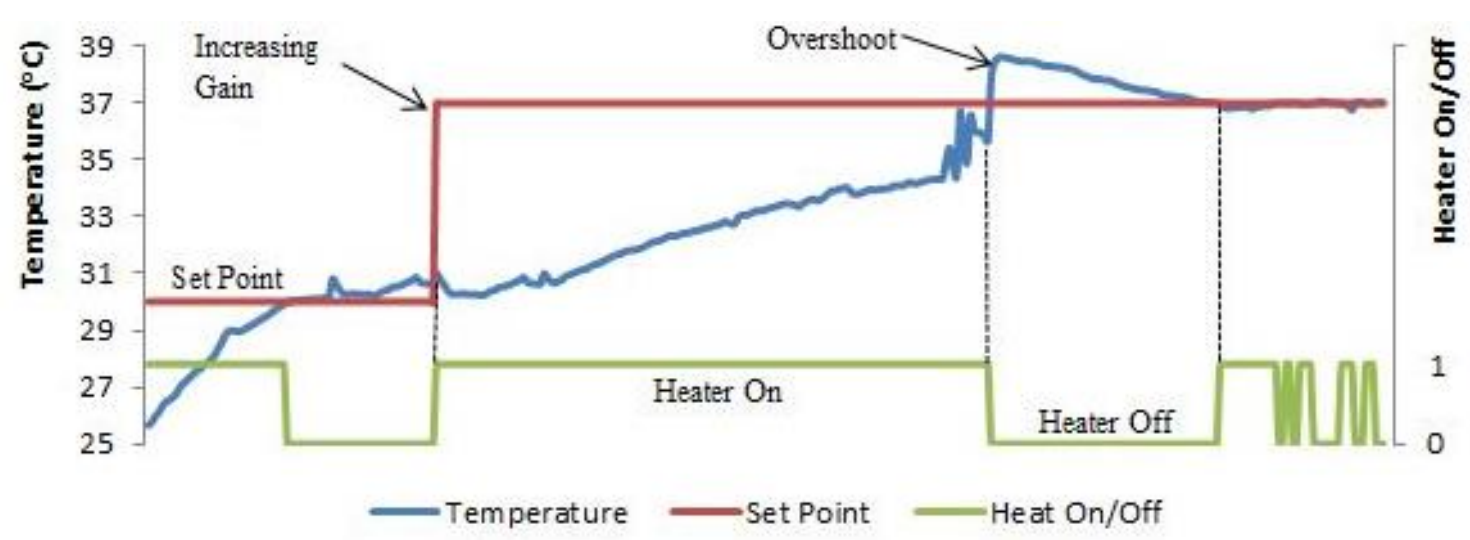

Figure 3. Results of the temperature set-point tracking experiments for the proposed miniature bioreactor system. The controller accuracy was in the range of $0.1-0.2^{\circ} \mathrm{C}$ from the set-point values and the temperature controller functionality was tested for temperature range between $25^{\circ} \mathrm{C}$ and $40^{\circ} \mathrm{C}$. 


\subsection{Anaerobic fermentation study using the miniature bioreactor}

In order to further evaluate the functionality of the proposed miniature bioreactor platform, series of anaerobic fermentation experiments using Saccharomyces cerevisae strain were carried out. The reactor was utilized to study the effect of substrate concentration (in this case glucose) on the cell growth. The industrial relevance of $\mathrm{S}$. cerevisiae strain in wine making and in beer production through anaerobic fermentation route justified the selection of S. cerevisiae strain for this work. As it can be observed in Figure 4, the cells grew instantaneously without any noticeable lag phase. A high cell concentration during inoculum stage might have allowed the yeast cells to quickly adapt to new environmental conditions in the miniature bioreactor and replicates. Another reason probably because the composition and conditions of the media in the reactor is very similar to the one in the inoculum and thus, shortened the acclimation period.

Concurrently to the decrease of the glucose level in the reactor (Figure 4), it is presumed that the cells exponential growth phase began just after an hour mark. As seen in Figure 4, glucose was rapidly consumed especially in the first 10-12 hours of fermentation. Cells grew at its maximum rate between 1 hour and 4 hours of fermentation time. After 4 hours, growth started to slow down and eventually came to a stationary growth phase after 22 hours of fermentation. The specific growth rate of cells at different initial substrates concentration is distinguishable by the slope of the cells growth profiles. Clearly, deceleration of cells growth was caused by the substantial reduction of the main substrates which in this case is the glucose level.

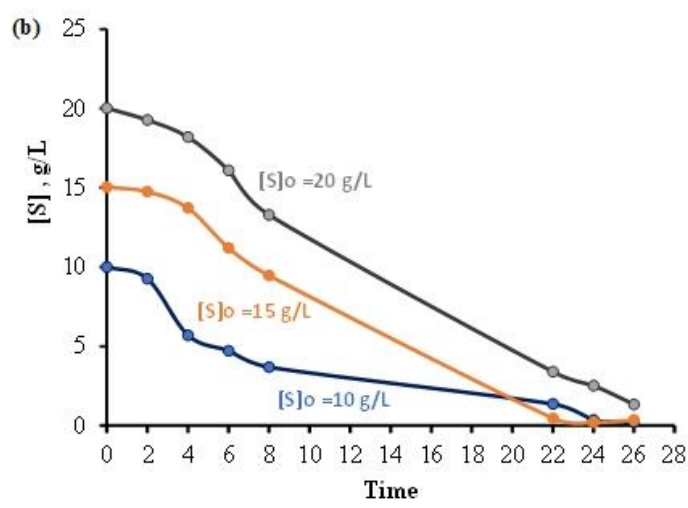

Figure 4. Cell growth (top) and glucose consumption (bottom) profiles of the S.cereviase batch fermentation experiments carried out at different substrates concentration in the proposed miniature bioreactor system.

Despite the differences in initial substrates concentration used, growth profiles attained were comparable for each of the fermentation processes performed.
Highest yield recorded was for yeast fermentation with starting substrate concentration of $20 \mathrm{~g} / \mathrm{L}$ where the cell growth rate, $\mu$ was calculated to be about 
$0.37 \mathrm{hr}^{-1}$. It seemed that as substrates concentration increases, cell growth rates increases as well - only not linearly. In order to further clarify the relation attained, Monod equation was applied. Growth parameters namely cell specific growth rates, $\mu$ and substrate concentrations, [S] for all fermentation experiments performed were used to estimate the growth constants $\mu_{\max }$ and $\mathrm{K}_{\mathrm{s}}$ based on the Monod equation. According to the calculations performed, values for $\mu$ $\max$ and $\mathrm{K}_{\mathrm{s}}$ achieved were $0.62 \mathrm{hr}^{-1}$ and $23.5 \mathrm{~g} / \mathrm{L}$, respectively. These values were comparable to the values attained in the literature for S.cerevisae fermentation grown on a single limiting substrate (Zelenev et al., 2005). Moreover, during each experiments, small bubbles $(\varnothing \sim 1-2 \mathrm{~mm})$ started to appear during exponential cell growth phase at the gas-liquid (oil layer) interfaces. This was expected because theoretically, in anaerobic yeast fermentation the carbon source (glucose) will be consumed by cells and converted into ethanol and carbon dioxide gas. Bubbles formed did not perturb with the magnetic stirrer bar mixing efficiency or interrupt the optical cells density readings. No significant volume loss due to evaporation was evident throughout the experiment. This is contrary to microbioreactor systems with working volume less than $1 \mathrm{~mL}$ where water evaporation often an issue during reactor operation (Schäpper et al., 2009). The presence of oil layer at the gas- liquid interface might have prevented (or significantly reduced) the water evaporation effect apart from preventing the diffusion of oxygen into the fermentation broth.

Whilst running numbers of reproducible batch cultivations in the proposed miniature bioreactor system is important to demonstrate its usefulness, it is also equally important to compare the results attained with cultivations performed using shake flask under the same conditions (i.e. same temperature, agitation rate and medium). Shake flask was chosen for the benchmarking experiments because shake flask are still the most preferred experimental tools in bioprocessing especially for screening and /or optimization purposes. The correspond ing yeast cultivation as in the miniature reactor was repeated using shake flask and the representative time course for the cell growth is shown in Figure 5. As it can be seen, although biomass yield for the cultivation performed in the flask was slig htly higher but cell growth profiles for both experiments were indeed similar. The specific cell growth rates for both cultivations were also comparable i.e. at about $0.2 \mathrm{hr}^{-1}$. In additional experiment, a small amount of bromothymol blue solution (a $\mathrm{pH}$ indicator) was added into the medium of the miniature bioreactor system. The reason was simply to observe $\mathrm{pH}$ changes throughout the fermentation process. As evident in Figure 5, the color of the broth changed from green which indicated $\mathrm{pH}$ close to neutral $(\sim \mathrm{pH} 7)$ to bright yellow that showed a mild acidic region at about $\mathrm{pH}$ 5.5. The color change also confirmed the fact that carbon dioxide gas was indeed being produced an $\mathrm{d}$ part of could have dissolved in water. When $\mathrm{CO}_{2}$ dissolves in water, it instantly reacts with $\mathrm{OH}^{-}$ions from the water to produce hydrogen ions, $\mathrm{H}^{+}$and forms carbonic acid, $\mathrm{H}_{2} \mathrm{CO}_{3}$ which then rapidly dissociates into bicarbonate, $\mathrm{HCO}_{3}{ }^{-}$(pKa1 at $25^{\circ} \mathrm{C}=6.36$ ) and also into carbonate, $\mathrm{CO}_{3}{ }^{2-}\left(\mathrm{pKa} 2\right.$ at $\left.25^{\circ} \mathrm{C}=10.32\right)$. This lowers the solution $\mathrm{pH}$ (Zainal Alam et al., 2012). 


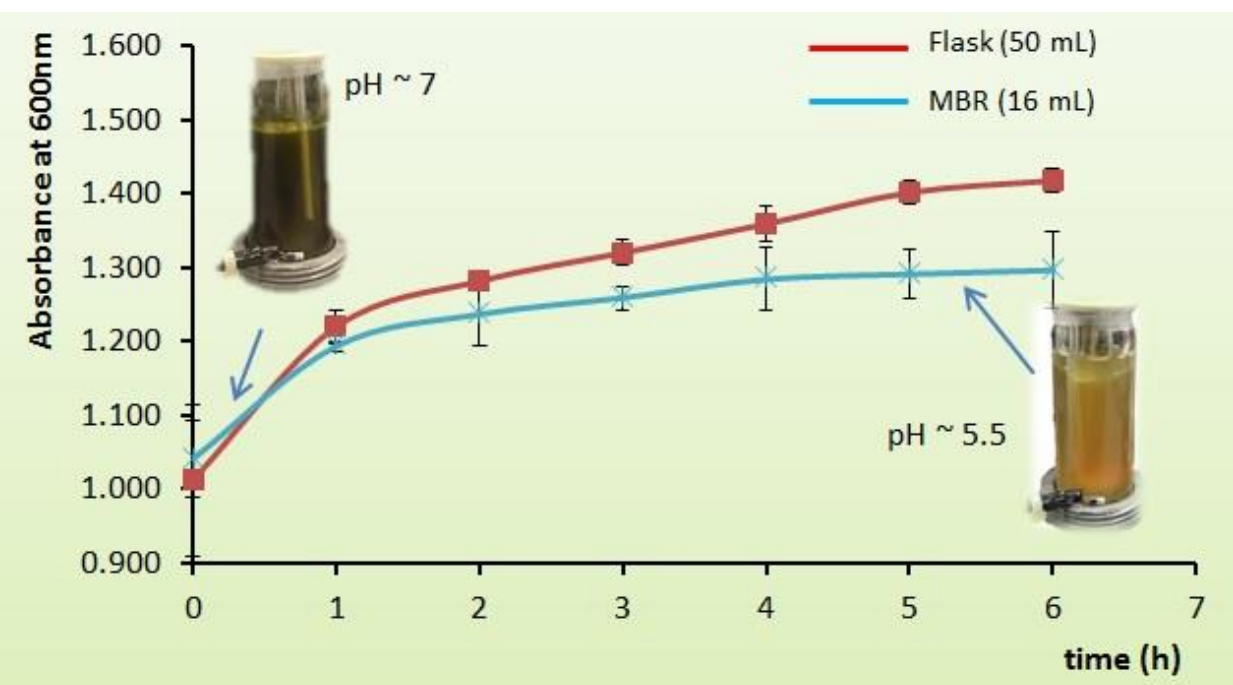

Figure 5. Comparison of cell growth profiles for S.cerevisae batch fermentation between experiments performed in the proposed miniature bioreactor system (working volume $=16$ $\mathrm{mL}$ ) and shake flask (working volume $=50 \mathrm{~mL}$ ). Inset shows the image of the reactor content as $\mathrm{pH}$ changes during the fermentation process

\section{CONCLUSION}

The paper presents the design of a miniature bioreactor system with working volume of approximately $16 \mathrm{~mL}$. Main features of the reactor included integrated optical density (OD) measurement, independent on/off temperature control, mixing and mixing via small magnetic stirrer bar. The workability of the device was assessed based on the device capacity to carry out series of batch fermentation experiments. As it turns out, the growth profiles of S.cerevisae batch fermentation processes attained in this study were comparable to those described in published works and industrial processes. This indicated that the proposed miniature bioreactor setup adequately mimics the results and/or profiles of a typical anaerobic yeast fermentation and thus, demonstrated that such miniature bioreact or system are indeed suitable to be used as alternative experimental tool in bioprocessing. Moreover, the device was designed with in mind that it will be a better alternative than shake flask (no integrated optical density measurement) and bench scale bioreactors (excessive workload before and after cultivation and requires large volume of medium).

\section{ACKNOWLEDGEMENT}

We would like to express our gratitude to the Ministry of Higher Education (MOHE), Malaysia and Universiti Teknologi Malaysia for funding the project. The project was funded by UTM Research University Prototype Grant Scheme (vote number, 00L49) and Fundamental Research Grant Scheme (vote number, 5F230).

\section{REFERENCES}

Blose, K. J., Krawiec, J. T., Weinbaum, J. S., and Vorp, D. A. (2014). Bioreactors for tissue engineering purposes A2 Orlando: pp177-185.

Bolic, A. (2018). Development and application of a milliliter-scale bioreactor for continuous microbial 
cultivations. Thesis of Doctoral Degree, Denmark Technical University.

Bolic, A., Larsson, H., Hugelier, S., Lantz, A.E., Krühne, U., and Gernaey, K.V. ( 2016). A flexible well-mixed millili ter-scale reactor with high oxygen tran sfer rate for microbial cultivation s. Chemical Engineering Journal. 303, 655-666.

Halimoon, H., Hussain, A., Kouzani, A., \& Alam, M. (2016). Aerobic fermentation of Saccharomeyes cerevisae in a miniature bioreactor made of low cost poly(methylmethacrylate) (PMMA) and poly(dimethylsiloxane) (PDMS) polymers. Sains Malaysiana, 45(6), 969-976.

Kheradmandnia, S., Hashemi-Najafabadi, S., Shojaosadati, S., Mousavi, S., and Malek Khosravi, K. (2014). Development of parallel miniature bubble column bioreactors for fermentation process. Journal of Chemical Technology \& Biotechnology, 90(6), 1051-1061.

Kirk, T. and Szita, N. (2013). Oxygen transfer characteristics of miniaturized bioreactor systems. Biotechnology and Bioengineering, 110(4), 1005-1019.

Krakau, K. (2016). Standard Operating Procedures for a Single-Use Fermenter. Thesis of Bachelor Degree, Technical University of Denmark.

Najafpour, G. (2007). Bioreactor Design. Biochemical Engineering and Biotechnology, pp.142-169.

Panatto, D., Amicizia, D., Bragazzi, N., Rizzitelli, E., Tramalloni, D., Valle, I. and Gasparini,R. (2015) 'Human Papillomavirus Vaccine. Advances in
Protein Chemistry and Structural Biology', 231-322.

Schäpper, D., Zainal Alam, M.N.H., Szita, N., Lantz, A.E. \& Gernaey, K.V. 2009. Application of microbioreactors in fermentation process development: A review. Analytical and Bioanalytical Chemistry 395(3): 679-695.

Schmideder, A., Severin, T., Cremer, J. and Weuster-Botz, D. (2015). A novel milliliter-scale chemostat system for parallel cultivation of microorganisms in stirred-tank bioreactors. Journal of Biotechnology, 210, .19-24.

Zainal Alam, M., Jaya Kumar, J., John Whyte, D., Doeven, E., \& Kouzani, A. (2018). A portable sensor for cell optical density measurement in microfluidic chips. Measurement and Control, 51(7-8), 213-222.

Zainal Alam, M., Schäpper, D. and Gernaey, K. (2010). Embedded resistance wire as a heating element for temperature control in microbioreactors. Journal of Micromechanics and Microengineering, 20(5): 055014.

Zainal Alam, M. N. H., Schäpper, D., and Gernaey, K. V. (2012). 'Establishment of a Gaseous $\mathrm{pH}$ concept in microbioreactors'. International Conference on Food Engineering \& Biotechnology ( ${ }^{\text {rd }}$ ICFEB), Sepang, Malaysia. ISSN: 2010-4618. Vol3: pg 228-234.

Zelenev, V.V., van Bruggen, A.H.C., and Semenov, A.M. (2005). Modeling wave-like dynamics of oligotrophic and copiotrophic bacteria along wheat roots in response to nutrient input from a growing root tip. Ecological Modelling. 188, $404-417$. 